
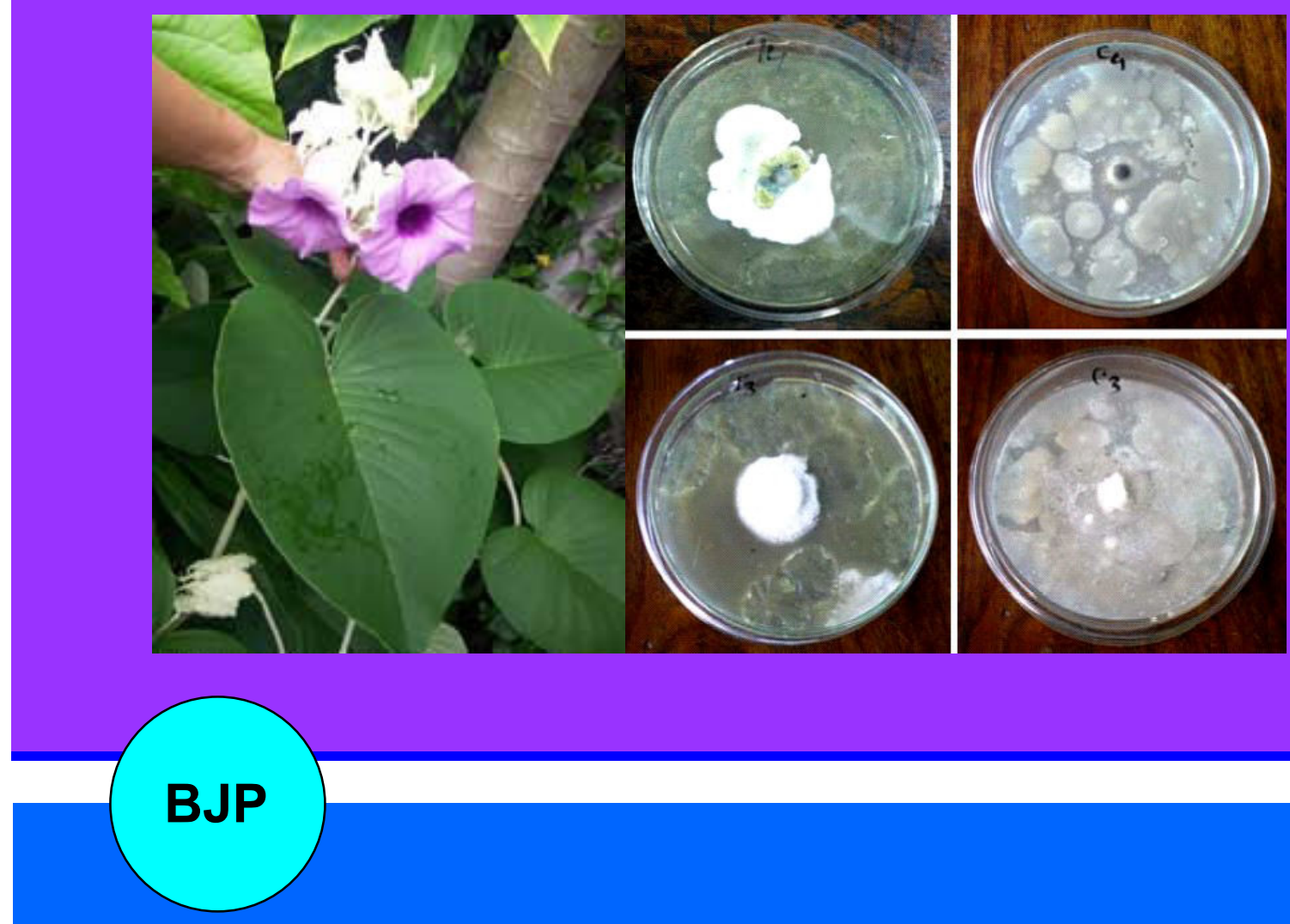

Bangladesh Journal of Pharmacology

Research Article

Antibacterial and antifungal properties of the methanol extract from the stem of Argyreia argentea 


\title{
Antibacterial and antifungal properties of the methanol extract from the stem of Argyreia argentea
}

\author{
Md. Atiar Rahman', Taslima Ahsan'1 and Saiful Islam² \\ ${ }^{1}$ Department of Biochemistry and Molecular Biology, University of Chittagong, Chittagong 4331, Bangladesh; \\ ${ }^{2}$ Bangladesh Council for Scientific and Industrial Research, Chittagong, Bangladesh.
}

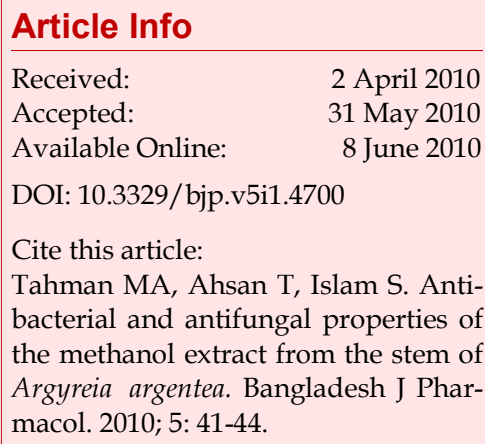

\section{Abstract}

Antibacterial properties of methanol extract of Argyreia argentea stem was studied on Gram positive and Gram negative bacteria by disc diffusion method. The extract showed zone of inhibition against Gram positive bacteria (Bacillus cereus, B. subtilis, B. megaterium and Staphylococcus aureus) and Gram negative bacteria [E. Coli, Salmonella typhae, S. paratyphae, Pseudomonous sp. (I), Pseudomonous sp. (II) and Shigella sonnei]. In addition, the extract was found effective against some fungi like Aspergillus flavous, Fusarium equiseti, Altenaria alternate, Aspergillus niger, Colletotrichum corphori.

\section{Introduction}

Argyreia argentea (family Convolvulaceae) is an evergreen shrub that is mainly found in different districts of Bangladesh (Uddin, 2006). It is widely used by the tribal communities of Chittagong Hill tracts (locally known to Chakma as bitarak rupar tola ludi) for the treatment of various diseases (boils, gastric, tumor, marasmus, paralysis and spermaforrhoea). However, a few scientific evaluations of this plant have been documented. This study interests to evaluate the antibacterial and antifungal activity of $A$. argentea methanol extract.

\section{Materials and Methods}

\section{Collection of plant}

The stems of $A$. argentea were collected from Chittagong Hill tracts, Bangladesh, in January 2009. The plant was taxonomically identified and authenticated by Bangladesh National Herbarium, Mirpur, Dhaka. The specimen is preserved in Bangladesh National Herbarium under the Plant Accession No. 34198.

\section{Preparation of crude extract}

The fresh stems of $A$. argentea were washed with distilled water immediately after collection. The collected stems were chopped into small pieces, air dried at room temperature for about 20 days and ground into powder to store in an airtight container. $790 \mathrm{~g}$ powder was macerated in $8 \mathrm{~L}$ pure methanol $(99 \%$ Anal-R) for 7 days at room temperature with occasional stirring. Methanol extract, 7 days later, was filtered off through a cotton plug and finally with a Whatman No. 1 filter paper. The extract was concentrated under reduced pressure below $50^{\circ} \mathrm{C}$ through rotatory vacuum evaporator. The concentrated extracts were collected in an eggplant flask and allow to air dry for complete evaporation of methanol. The whole process was repeated three times and finally, 15 g greenish colored, concentrated stem extract was obtained $(1.9 \% \mathrm{w} / \mathrm{w})$ which was kept in refrigerator to $4^{\circ} \mathrm{C}$.

\section{Bacterial strains}

Gram positive (Bacillus cereus, B. subtilis, B. megaterium and Staphylococcus aureus) and Gram negative (E. Coli, Salmonella typhae, S. paratyphae, Pseudomonous sp. (I), 
Pseudomonous sp. (II) and Shigella sonnei) bacterial species were used.

\section{Fungal strains}

Three human pathogens (Aspergillus fumigates, A. flavous and $A$. niger) and three plant pathogens (Fusarium equiseti, Altenaria alternate and Colletotrichum corphori) were used.

\section{Preparation of stem extracts solution}

A measured amount of $200 \mathrm{mg} \mathrm{A}$. argentea stem extract was dissolved in $2 \mathrm{~mL}$ of methanol to give a solution of known concentration (100 pg/pL). Methanol was chosen as solvent because, in addition to the complete dissolution of the crude extracts, it has no inhibitory effect on the cultures.

\section{Preparation of sample discs}

The sample discs of about $4 \mathrm{~mm}$ in diameter were cut by punching machine from Whatman No. 1 filter paper. The discs were taken in a petri dish and sterilized by autoclave, dried in oven at $180^{\circ} \mathrm{C}$.

\section{Standard antibiotic disc}

Kanamycin antibiotic disc (Oxoid, England,) with concentrations of $30 \mathrm{pg} /$ disc was used as standard to compare with the sample.

\section{Assay for antibacterial activity}

Antibacterial activity of plant extract was determined by disc diffusion method (Bauer et al., 1966). All the test bacterial species were collected from the Research Laboratories of the Department of Microbiology, University of Chittagong. Dried filter paper discs (4 $\mathrm{nm}$ in diameter) impregnated that controls the diffusion of molecules through agar gel. The plates were then incubated at $37^{\circ} \mathrm{C}$ for 24 hours to allow maximum growth of the microorganisms. If the test materials have any antibacterial activity, it will inhibit the growth of the microorganisms giving the clear distinct zone around the disc called "zone of inhibition". The antibacterial activity of the test material was determined by measuring the diameter of the zones of inhibition in millimeter with transparent scale.

\section{Standard antifungal disc}

Grisofulvin (Glaxosmithkline, Chittagong) 100 pg/mL was used as standard to compare the tested results under identical conditions.

\section{Assay for antifungal activity}

The poisoned food technique (Grover and Moore, 1962) was used to screen for antifungal activity of plant extract. Potato Dextrose Agar (PDA) was used as a culture medium. Each extract was dissolved in methanol and then mixed with sterilized PDA to obtain a final concentration of $2 \mathrm{mg} / \mathrm{mL}$. From this $20 \mathrm{~mL}$ medium of each extract was poured into separate sterilized petri plate and allowed it to solidify. Inoculation was done at the center of each plate with a 5 $\mathrm{mm}$ mycelium block for each fungus. Mycelium block was prepared with the help of cork borer from the growing area of a five day old culture of the test fungi PDA. The blocks were placed at the center of each petriplate in an inverted position to get greater contact of the mycelium with the culture medium. The inoculated plate was incubated at $25^{\circ} \mathrm{C}$. The experiment was repeated for three times. Proper control (PDA) without extracts was also maintained. After five days of incubation the diameter of fungal colony was measured in $\mathrm{mm}$.

The percentage of inhibition of mycelial growth of the test fungus was calculated by the following formula:-

$$
\text { (C-T) }
$$

$\mathrm{I}=----\times 100$

C

Where, $\mathrm{I}=$ Percentage of inhibition; $\mathrm{C}=$ Diameter of the fungal colony in control; $\mathrm{T}=$ Diameter of the fungal colony in treatment.

\section{Results}

Table I showed that $1,000 \mathrm{pg} /$ disc of extract exhibited $13,14,10$ and $15 \mathrm{~mm}$ zone of inhibition against Gram positive bacteria Bacillus cereus, B. subtilis, B. megaterium and Staphylococcus aureus respectively, and 14, 13, 10, 14, 12 and $12 \mathrm{~mm}$ zone of inhibition against Gram negative bacteria namely E. coli, Salmonela typhi, Salmnela paratyphi (Figure 1A), Pseudomonous sp. (I) (Figure 1B), Pseudomonous sp. (II) (Figure 1C) and Shigella sonnei (Figure 1D), respectively. On the other hand, standard antibiotic kanamycin (30 $\mu \mathrm{g} /$ disc) showed more significant antibacterial activity against all tested Gram positive and Gram negative bacteria showing the larger zone of inhibition in every case. This results indicate that $A$. argentea stem extract has promising antibacterial activity. In the assay of antifungal activity (Table II), A. argentea stem extract inhibited the mycelia growth of Aspergillus flavous, Fusarium equiseti (Figure 2B), Altenaria alternate (Figure 2A) and Colletotrichum corphori with the \%inhibition of $44.4,66.7,44.4$ and $75.6 \%$, respectively, whereas no inhibition was observed against Aspergillus niger (Figure 2C) and Aspergillus fumigates.

\section{Discussion}

Plants produce a huge variety of secondary compounds as natural protection against microbial and insect attack. Some of these compounds are toxic to animals, 


\begin{tabular}{|c|c|c|}
\hline \multicolumn{3}{|c|}{ Table I } \\
\hline \multicolumn{3}{|c|}{ Diameter of zone of inhibition against bacteria } \\
\hline \multirow[t]{2}{*}{ Bacteria } & \multicolumn{2}{|c|}{ Diameter of zone of inhibition (mm) } \\
\hline & $\begin{array}{c}\text { Kanamycin } \\
(30 \text { pg/disc }) \\
(\mathrm{mm})\end{array}$ & $\begin{array}{l}\text { A. argentea extract } \\
(1,000 \mathrm{pg} / \text { disc }) \\
(\mathrm{mm})\end{array}$ \\
\hline \multicolumn{3}{|l|}{$\begin{array}{l}\text { Gram positive bac- } \\
\text { teria }\end{array}$} \\
\hline Bacillus cereus & 28 & 13 \\
\hline Bacillus subtilis & 32 & 14 \\
\hline $\begin{array}{l}\text { Bacillus megatari- } \\
\text { um }\end{array}$ & 26 & 10 \\
\hline $\begin{array}{l}\text { Staphylococcus } \\
\text { aureus }\end{array}$ & 30 & 15 \\
\hline \multicolumn{3}{|l|}{$\begin{array}{l}\text { Gram negative } \\
\text { bacteria }\end{array}$} \\
\hline E. Coli & 30 & 14 \\
\hline Salmonella typhae & 30 & 13 \\
\hline $\begin{array}{l}\text { Salmonella para } \\
\text { typhae }\end{array}$ & 30 & 10 \\
\hline $\begin{array}{l}\text { Pseudomonous Sp. } \\
\text { (I) }\end{array}$ & 29 & 14 \\
\hline $\begin{array}{l}\text { Pseudomonous Sp } \\
\text { (II) }\end{array}$ & 30 & 12 \\
\hline Shigella sonnei & 28 & 12 \\
\hline
\end{tabular}

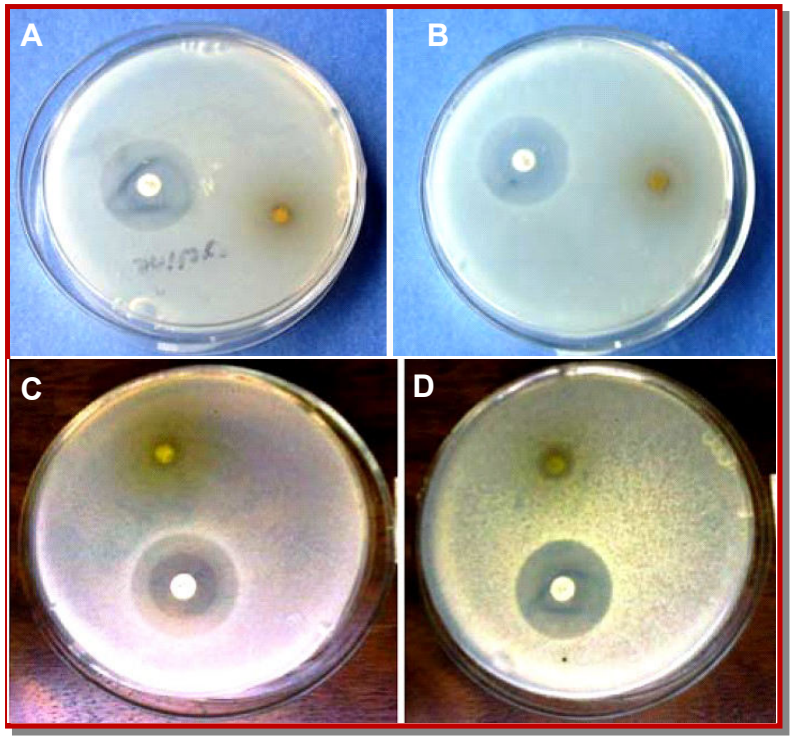

Figure 1: Zone of inhibition showed by the A. argentea extract (A-C) against the bacterial strains (A) Salmonella para typhae; (B) Pseudomonous Sp. (I); (C) Pseudomonas Sp. (II) and (D) Shigella sonnei (inhibition zone in presence of kanamycin)

but others may not be toxic. Indeed, many of these compounds have been used in the form of whole plants or plant extracts for food or medical applications in human (Wallace, 2004) because plants are the natural reservoir of many antimicrobial, anti-cancer agents, analgesics, anti-diarrheal, antifungal as well as various

\begin{tabular}{|c|c|c|}
\hline \multicolumn{3}{|c|}{ Table II } \\
\hline \multicolumn{3}{|c|}{ In vitro antifungal activities of $A$. argentea extract } \\
\hline \multirow[t]{2}{*}{ Fungus } & \multicolumn{2}{|c|}{$\begin{array}{l}\% \text { inhibition of fungal mycelial } \\
\text { growth }\end{array}$} \\
\hline & $\begin{array}{l}\text { A. argentea extract } \\
(2 \mathrm{mg} / \mathrm{mL})\end{array}$ & $\begin{array}{l}\text { Grisofulvin } \\
(100 \mathrm{pg} / \mathrm{mL})\end{array}$ \\
\hline \multicolumn{3}{|l|}{ Human pathogen } \\
\hline $\begin{array}{l}\text { Aspergillus fumiga- } \\
\text { tus }\end{array}$ & 0 & 0 \\
\hline Aspergillus flavous & 44.4 & 66.7 \\
\hline Aspergillus niger & 0 & 22.2 \\
\hline \multicolumn{3}{|l|}{ Plant pathogen } \\
\hline Fusarium equiseti & 66.7 & 72.2 \\
\hline Altenaria alternata & 44.4 & 66.7 \\
\hline $\begin{array}{l}\text { Colletotrichum cor- } \\
\text { phori }\end{array}$ & 75.6 & 66.7 \\
\hline
\end{tabular}
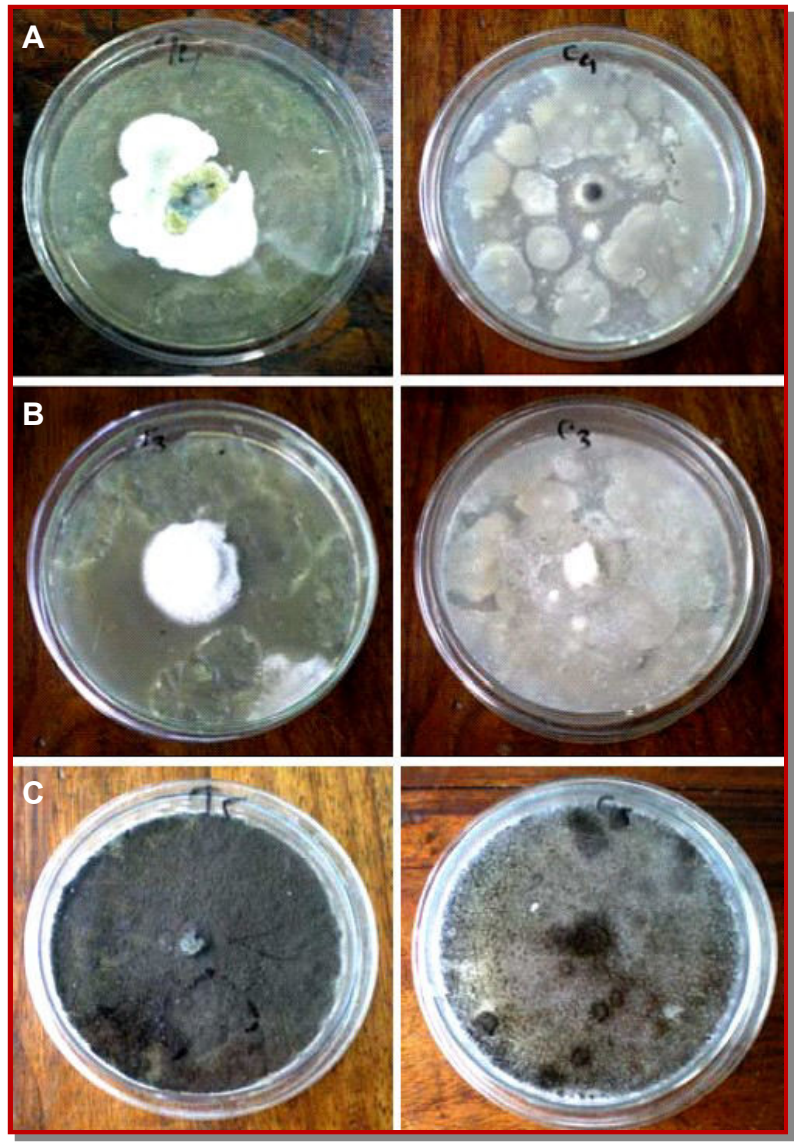

Figure 2: Percentage of fungal growth inhibition showed by the A. argentea stem extract against the fungal strains (A) Altenaria alternate; (B) Fusarium equiseti; (C) Aspergillus niger. Left column is treated and right column is control

therapeutic activities (Lucy and DaSilva, 1999). Acceptance of medicines from such plant origin as an alternative form of healthcare is increasing because they 
are serving as promising sources of novel antibiotic prototypes (Rabe and Van Staden, 1997; Koduru et al., 2006). Some of the phytochemical compounds e.g. glycoside, saponin, tannin, flavonoids, terpenoid, alkaloids, have variously been reported to have antimicrobial activity (Okeke et al., 2001; Ebi and Ofoefule, 1997).

In the current study, the results of testing the crude extracts for antimicrobial activities against 10 bacterial and 6 fungal species might be due to the presence of some sorts of bioactive or inhibitory compounds or factors in the extract or synergism by the existence of some compounds or factors in the extract of A. argentea.

\section{Conclusion}

This demonstrates that the methanol extract of $A$. argentea stem extract exhibits antibacterial and antifungal effect in experimental models which therefore offer a scientific basis for using this plant as a good source of traditional microbiological references.

\section{Acknowledgement}

The authors wish to pay thankful gratitude to Bangladesh Council for Scientific and Industrial Research Laboratories, Chittagong for their continuous support in progress of this study.

\section{References}

Bauer AW, Kirby E, Sherris JC, Turck M. Antibiotic susceptibility testing by a standardized single disk method. Am J Clin Pathol. 1966; 45: 493-96.

Ebi GC, Ofoefule SI. Investigating into folkloric antimicrobial activities of Landolphia owerrience. Phytother Res. 1997; 11: 149-51.

Grover RK, Moore JD. Toximetric studies of fungicides against brown rot organism- Sclerotinia fructicola and S. laxa. Phytopathology 1962; 52: 876-80.

Koduru S, Grierson DS, Afolayan AJ. Antimicrobial activity of Solanum aculeastrum. Pharm Biol. 2006; 44: 283-86.

Lucy H, DaSilva EJ. Medicinal plants: A re-emerging health aid. Electronic J Biotech. 1999; 2: 56-70.

Okeke MI, Iroegbu CU, Eze EN, Okoli AS, Esimone CO. Evaluation of extracts of the root of Landolphia owerrience for antibacterial activity. J Ethnopharmacol. 2001; 78: 119-27.

Rabe T, Van Staden J. Antibacterial activity of South African plants used for medicinal purposes. J Ethnopharmacol. 1997; 56: 81-87.

Uddin SN. Tradition uses of ethnomedicinal plants of the Chittagong Hill Tracts. Rahman MM (ed). Dhaka, Bangladesh National Herbarium, 2006, p 372.

Wallace RJ. Antimicrobial properties of plant secondary metabolites. Proc Nutr Soc. 2004; 63: 621-29. 